\title{
Properties of DNA fragmentation activity generated by ATP depletion
}

\author{
N Nakamura ${ }^{1}$ and Y Wada ${ }^{*, 1}$ \\ 1 Department of Molecular Medicine, Osaka Medical Center and Research \\ Institute for Maternal and Child Health, 840 Murodo-cho, Izumi, Osaka 594- \\ 1101, Japan \\ * Corresponding author: Y Wada, Osaka Medical Center and Research Institute \\ for Maternal and Child Health, 840 Murodo-cho, Izumi, Osaka 594-1101, \\ Japan. Tel: +81-725-56-1220; Fax: +81-725-57-3021; \\ E-mail: j61638@center.osaka-u.ac.jp
}

Received 1.12.99; revised 25.1.00; accepted 8.2.00

Edited by JC Reed

\begin{abstract}
Internucleosomal DNA fragmentation is generally perceived as one of the characteristic features of apoptosis, most of which are driven by caspase activation dependent upon ATP. On the other hand, ATP depletion has been reported to induce apoptosis accompanying DNA fragmentation. To address this apparent paradox, we analyzed the DNA-fragmenting activity generated in ATP-depleted cells. In HL-60 promyelocytic leukemia cells cultured in glucose-free medium with oligomycin, internucleosomal DNA fragmentation occurred as an early event. The DNA fragmentation was blocked by serine protease inhibitors but not by caspase inhibitors. Consistently, ICAD/DFF45 could not inhibit the DNAfragmenting activity of the ATP-depleted cytosol in a cell-free system. When ATP was supplied to the cell-free assay, $80 \%$ of the DNA-fragmenting activity was lost. The reduced activity was then restored by proteasome inhibitors, suggesting a role of proteasome to protect from a cellular insult derived from ATP-depletion. Cell Death and Differentiation(2000)7,477-484.
\end{abstract}

Keywords: DNA fragmentation; endonuclease; serine protease; proteasome; ATP; caspase

Abbreviations: BrdU, 5-bromo-2'-deoxyuridine; DCl, 3,4-dichloroisocoumarin; DEVD, $\mathrm{N}$-acetyl-Asp-Glu-Val-Asp-aldehyde; ELISA, enzyme-linked immunosorbent assay; GST, glutathione Stransferase; LLnL, N-acetyl-leucinyl-leucinyl-norleucinal; TLCK, $\mathrm{N}$-tosyl-L-lysyl chloromethyl ketone; TPCK, tosyl-L-phenylalanyl chloromethyl ketone; VAD, carbobenzoxyl-Val-Ala-Asp-fluoromethyl ketone

\section{Introduction}

In multicellular organisms, a wide variety of stimuli induce organized cell death called apoptosis. The apoptotic process is characterized by an amplifying proteolytic cascade in which upstream (initiator) caspase mediate the activation of down- stream (effector) caspases. Mitochondria intervene between these two classes of caspase, and play a decisive role in the death pathway by releasing apoptogenic molecules including cytochrome c. ${ }^{1-7}$ Released cytochrome $\mathrm{c}$ in the cytosol forms a complex called apoptosome with Apaf-1 to catalyze the activation of caspase 9 in an ATP-dependent manner. ${ }^{8-14}$ In functional apoptosome, hydrolysis of the high-energy bond of dATP/ATP is required for sequential conformational changes of Apaf- 1 in the course of binding to cytochrome $c$ and procaspase-9, resulting in recruitment of the substrates of caspase-9, procaspase- 3 and possibly procaspase- $7.9,12,13$ dATP/ATP hydrolytic energy is also used for overcoming inhibition of caspase activation by an anti-apoptotic protein, $\mathrm{Bcl}-2{ }^{15}$ Also, in experiments using whole cells, ATP was required for the activation of caspase-3 in response to many apoptotic stimuli. ${ }^{16,17}$ Activated caspases can initiate cleavage of other cellular substrates, producing the features of apoptosis characterized morphologically by condensation and fragmentation of nuclei and cells and biochemically by fragmentation of chromosomal DNA into nucleosomal units. ${ }^{18}$ These studies substantiated the requirement of ATP for caspase activation in the apoptotic process.

In several studies, energy deficiency or ATP depletion induced apoptosis rather than necrosis. ${ }^{19-24}$ For example, inhibition of glucose transport by cytochalasin B induced apoptosis in an interleukin 3 (IL-3)-dependent mast cell line, IC.DP cells. ${ }^{20}$ Depletion of intracellular ATP by uncoupling the mitochondrial ATPase induced apoptotic cell death displaying DNA fragmentation in IL-3-dependent pro-B line cells. ${ }^{19}$ More recently, energy deficiency due to hypoxia and hypoglycemia has been shown to cause apoptosis, which is possibly mediated by expression of hypoxia-inducible factor $1 .{ }^{21}$ In light of the implication of ATP in apoptosome as described above, however, it seems unlikely that caspases are activated in ATP-depleted cells.

In the present study, promyelocytic leukemia HL-60 cells were cultured under ATP-depleted conditions. We focused on internucleosomal DNA fragmentation, and analyzed the properties of the molecular pathway, including proteases, leading to DNA fragmentation in a cell-free system. This study demonstrated that the process involves serine protease and that the downstream endonuclease is distinct from CAD/DFF40. Proteasome is also implicated in a possible cellular mechanism against this pathological event.

\section{Results}

\section{DNA fragmentation induced by ATP depletion}

Cellular ATP level decreases under glucose-free culture, and an inhibitor of $F_{0}$ unit of mitochondrial ATP synthase, oligomycin, promotes ATP depletion. In HL-60 cells cultured in glucose-free medium with $20 \mu \mathrm{M}$ oligomycin, the ATP level 
rapidly declined to less than $10 \%$ of the initial level of $2 \mathrm{mM}$ in $1.5 \mathrm{~h}$ (Figure 1A). Agarose gel electrophoresis of the DNA extracted from the ATP-depleted cells revealed internucleosomal fragmentation, which was detected after $1 \mathrm{~h}$ of incubation and became obvious after $2 \mathrm{~h}$ (Figure 1B). Incubation over several hours induced non-segmental cleavage, yielding a smear pattern (data not shown), indicating that the DNA fragmentation observed herein was
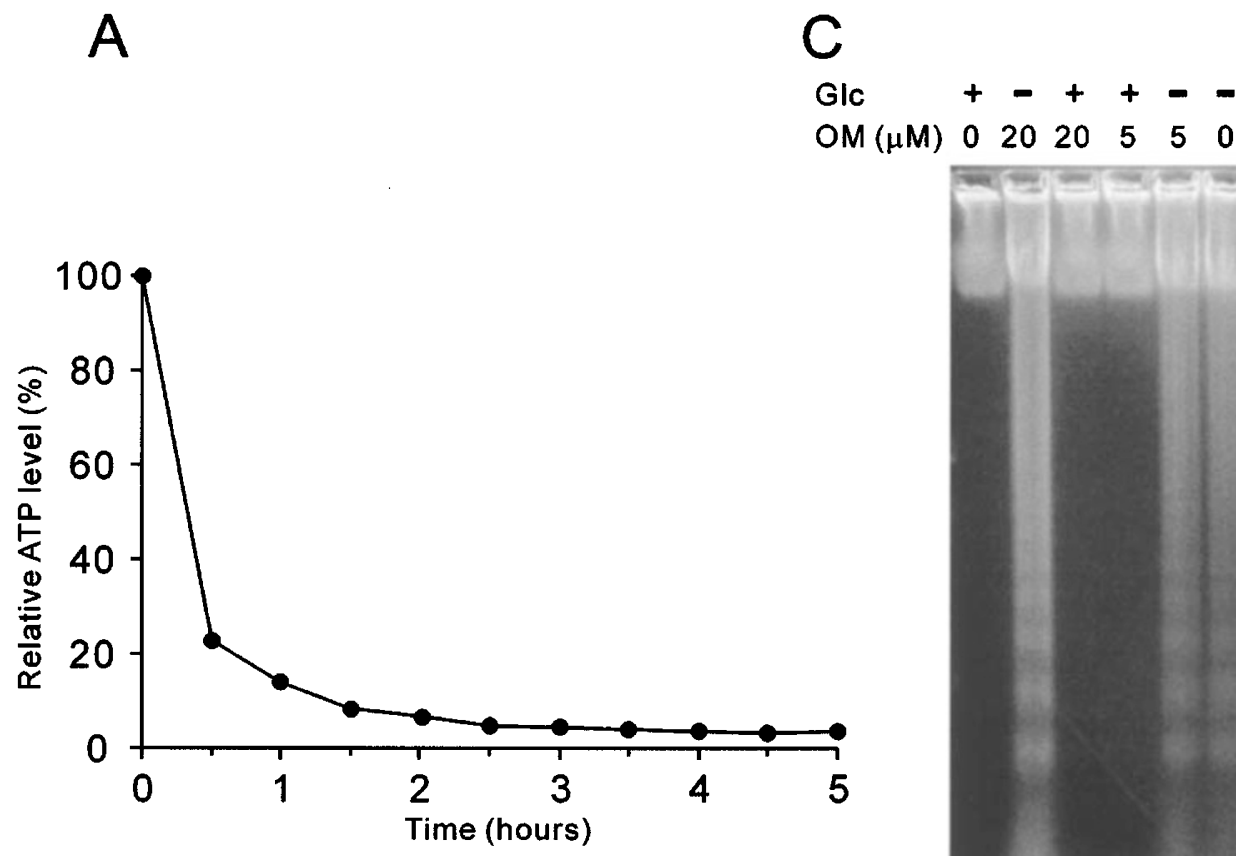

M $(\mu M) \quad 0 \quad 2020 \quad 5 \quad 5 \quad 0$

B

Time (hours)

M 00.5111 .5222 .5333 .544 .55

D
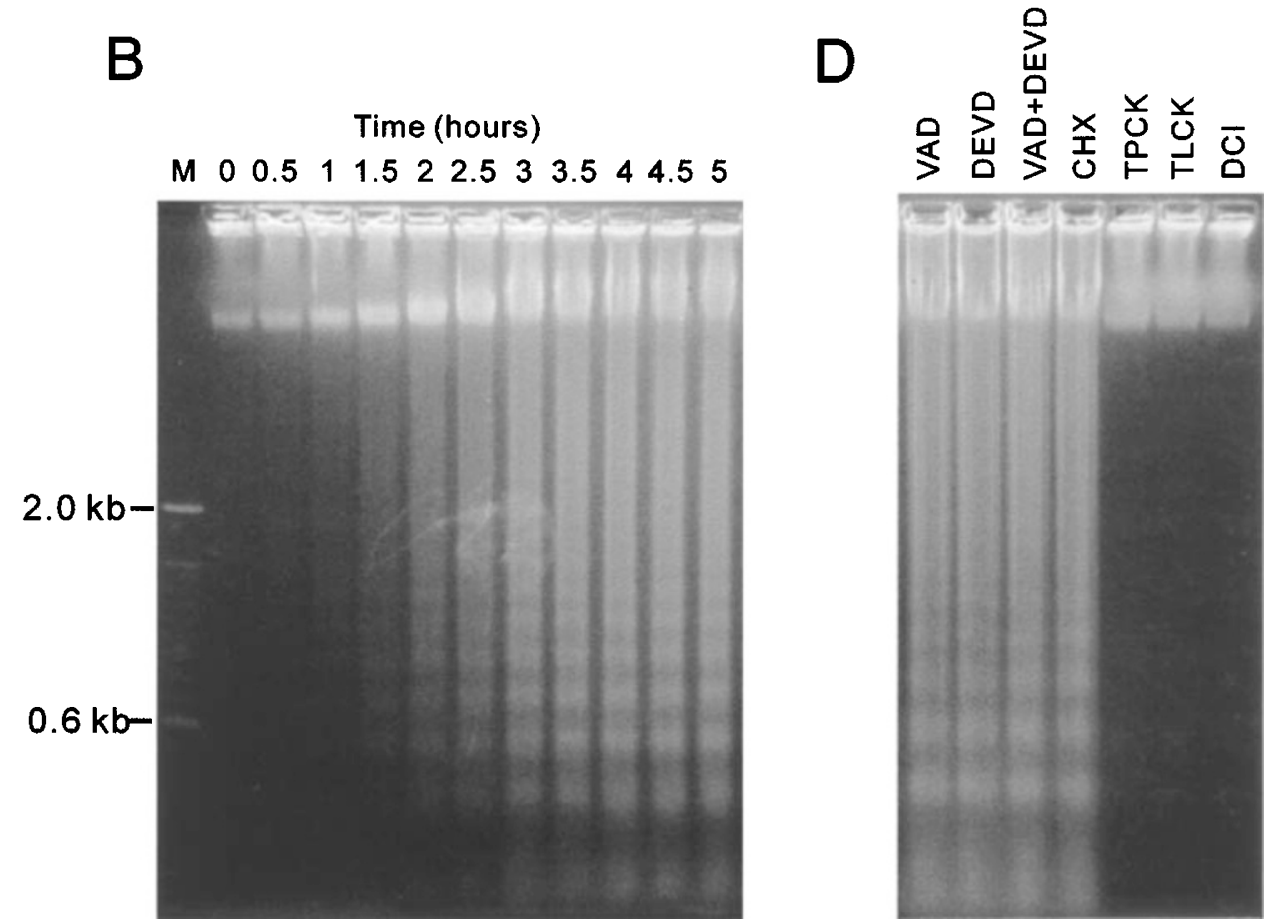

Figure 1 ATP depletion and internucleosomal DNA fragmentation. HL-60 cells were cultured in glucose-free medium with oligomycin. (A) Time-course of intracellular ATP level was determined by luciferin-luciferase method. (B) DNA fragmentation was analyzed by electrophoresis on $1.2 \%$ agarose gel followed by ethidium bromide staining. Each lane contains DNA from $1 \times 10^{7}$ treated or untreated cells. (C) Cells were cultured for $4 \mathrm{~h}$ under the indicated conditions. (Glc: glucose; OM: oligomycin) (D) Effect of protease inhibitors. Cells were cultured in glucose-free medium with $20 \mu \mathrm{M}$ oligomycin for $4 \mathrm{~h}$ in the presence of $100 \mu \mathrm{M}$ reagents. M, DNA size marker 
an early phase of cell alterations under ATP depletion. DNA fragmentation was not observed in the presence of $11 \mathrm{mM}$ glucose in the culture medium even if mitochondrial ATP generation was inhibited by oligomycin (Figure 1C). On the other hand, deprivation of glucose, without oligomycin, induced weak but apparent activity of DNA fragmentation.

\section{Effects of protease inhibitors on the DNA fragmentation activity}

Activity that induces internucleosomal fragmentation in response to various stimulation has been identified in different cells, and is blocked by inhibitors of caspases and/ or other proteases. ${ }^{26-33}$ In order to examine the possible involvement of proteases in inducing fragmentation, cellpermeable inhibitors were added to the culture medium of $\mathrm{HL}$ 60 cells. As shown in Figure 1D, a broad spectrum inhibitor of caspases, VAD, as well as an inhibitor, DEVD, specific to caspases-3 and 7 did not affect DNA fragmentation. In contrast, serine protease inhibitors, TPCK, TLCK and DCI, blocked the activity. The DNA fragmentation induced by ATP depletion did not require de novo synthesis of proteins, since DNA fragmentation was not affected by cycloheximide (Figure 1D).

\section{Cell-free assay of DNA fragmentation}

DNA fragmentation activity in the cell lysate was examined in a cell-free system. HL-60 cells were cultured in glucose-free medium containing $20 \mu \mathrm{M}$ oligomycin for $4 \mathrm{~h}$, and the cytosolic fraction was prepared from the cells and incubated with intact nuclei prepared from untreated cells. The activity was measured by ELISA of the fragmented DNA. DNA fragmentation was detectable with an up to 32-fold dilution of cytosol in this system (Figure 2A), and even an eightfold dilution of cytosol exhibited marked fragmentation after incubation for at least $10 \mathrm{~min}$ (Figure 2B). Dose-dependent inhibition of DNA fragmentation by TPCK was also demonstrated in the cell-free system (Figure 2C).

\section{DNA fragmentation activity induced by ATP depletion was independent of CAD/DFF40}

CAD/DFF40 is a well-characterized endonuclease responsible for the DNA fragmentation downstream of the caspase pathway. It is activated in the cytosol by the cleavage of an inhibitory molecule, ICAD/DFF45, that binds and stabilizes CAD/DFF40. Exogenous ICAD/DFF45 prevents CAD/DFF40 in a cell-free system. ${ }^{25,34}$ As caspase inhibitors could not block DNA fragmentation in ATP-depleted cells (Figure 1), CAD/DFF40 was presumably not involved in the execution of observed DNA cleavage. To confirm this, we examined the effect of ICAD/DFF45 on DNA fragmentation. DNA fragmentation induced by FAS ligation or etoposide was abrogated by recombinant ICAD/DFF45 in a dose-dependent manner in Jurkat cells (Figure $3 A$ ). In contrast, the activity in ATPdepleted cytosol was resistant to ICAD/DFF45 in Jurkat cells and HL-60 (Figure 3A,B).
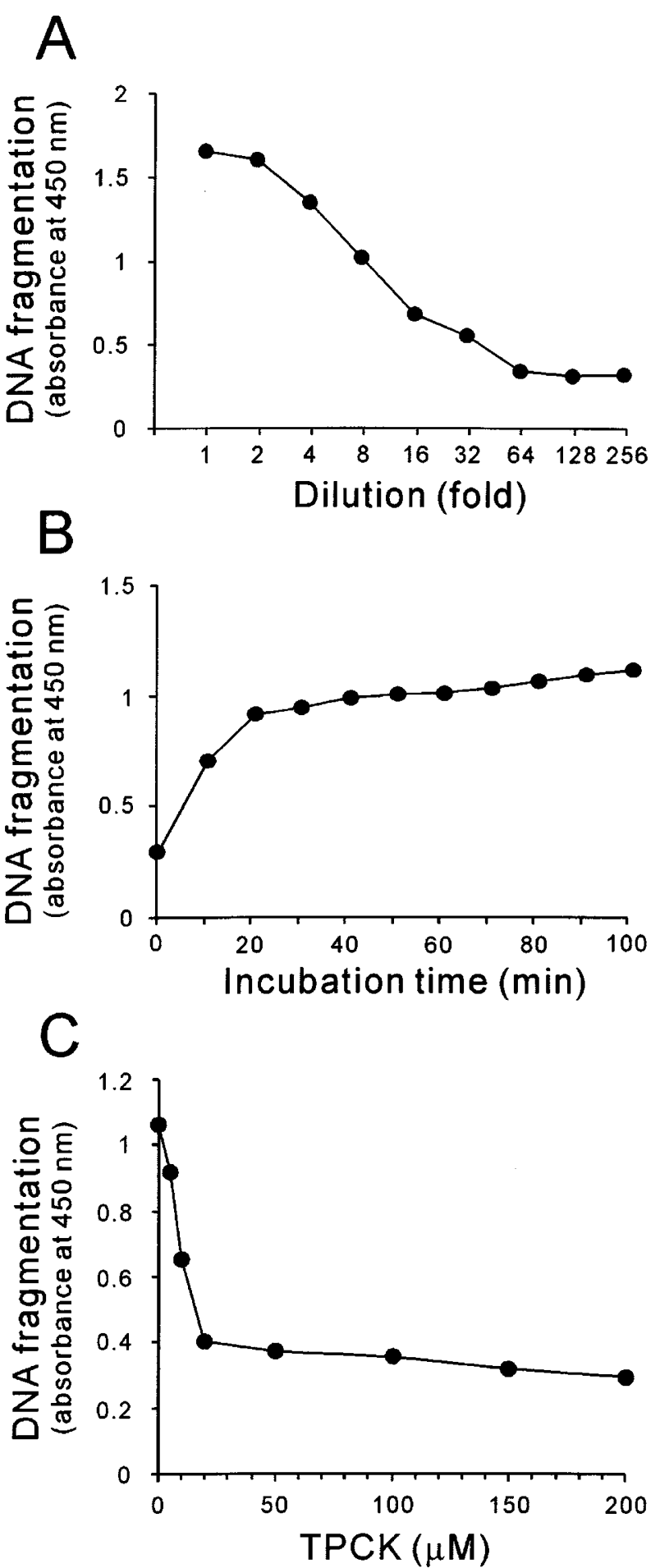

Figure 2 Cell-free assay of DNA-fragmenting activity of ATP-depleted cytosol. (A) ATP-depleted cytosol $(2.5 \mathrm{mg}$ protein) was serially diluted with nucleus buffer and incubated with $1 \times 10^{7} \mathrm{BrdU}$-labeled nuclei in $1 \mathrm{ml}$ reaction volume at $37^{\circ} \mathrm{C}$ for $1 \mathrm{~h}$. Fragmented DNA was measured by ELISA. (B) Timecourse of DNA fragmentation generated by eightfold dilution of cytosol. (C) Effect of TPCK on the DNA-fragmenting activity of eightfold diluted cytosol 

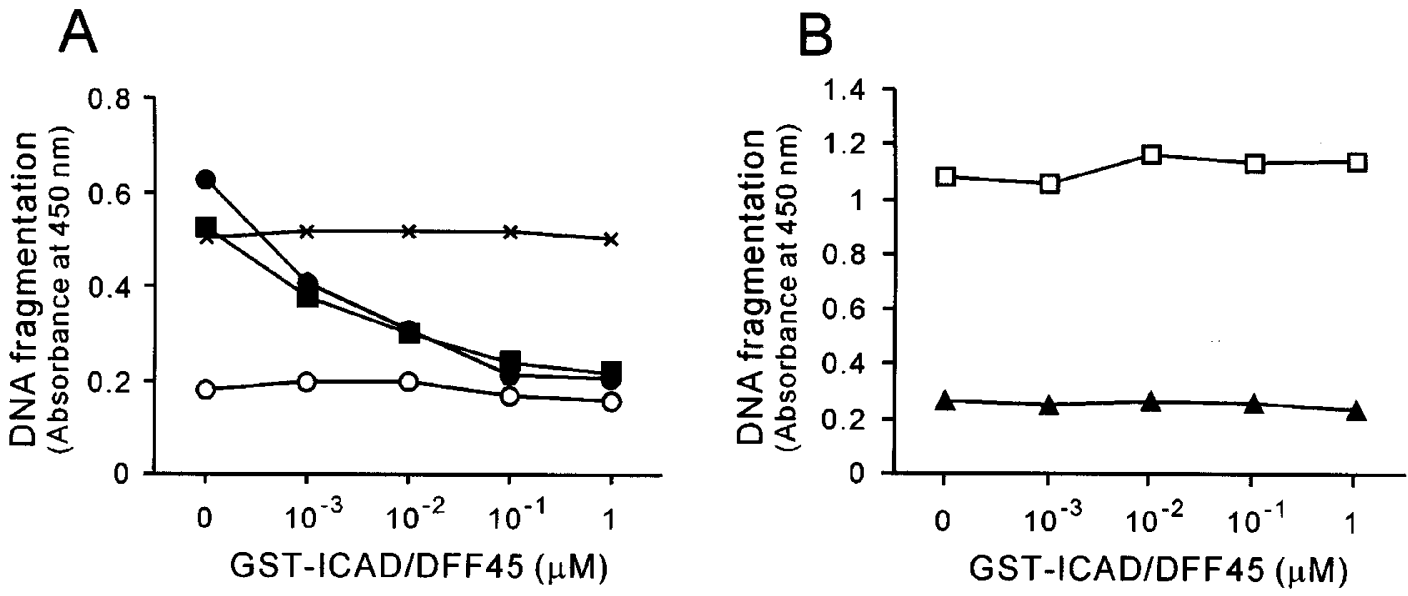

Figure 3 Effect of exogenous ICAD/DFF45 on DNA-fragmenting activity of ATP-depleted cytosol. (A) Jurkat cells were incubated with anti-FAS antibody (closed circles), control IgM (open circles) or etoposide (closed squares), or cultured in glucose-free medium with $20 \mu \mathrm{M}$ oligomycin for $6 \mathrm{~h}$ (crosses). Cytosol (1 mg/ml) prepared from the cells was incubated with $10 \mu \mathrm{M}$ DEVD followed by various concentrations of GST-ICAD/DFF45 in $20 \mu \mathrm{l}$ reaction volume, each at $4{ }^{\circ} \mathrm{C}$ for 30 min. The mixture was then incubated with $5 \times 10^{5}$ BrdU-labeled nuclei at $30^{\circ} \mathrm{C}$ for $2 \mathrm{~h}$, and subjected to ELISA of fragmented DNA. (B) HL-60 cells were cultured under normal conditions (closed triangles) or in glucose-free medium with $20 \mu \mathrm{M}$ oligomycin for $4 \mathrm{~h}$ (open squares). Cytosol of the cells was prepared and subjected to the same treatment as Jurkat cells except for incubation with BrdU-labeled nuclei at $37^{\circ} \mathrm{C}$ for $1 \mathrm{~h}$ before ELISA

\section{Effect of ATP supply to ATP-depleted cytosol}

To explore the ATP-dependent process that may relate to or antagonize DNA fragmentation, ATP-depleted cytosol at an eightfold dilution was incubated with $1 \mathrm{mM}$ ATP prior to addition to intact nuclei. Approximately $80 \%$ of the DNAcleaving activity was lost by this ATP supply (Figure 4), and the suppression reached a plateau after 40 min of preincubation with ATP addition (data not shown). Although it could be speculated that ATP-dependent DNA fragmentation, possibly mediated by caspases, was activated and contributed to the remaining $20 \%$ activity, caspase inhibitors did not change the fragmentation. On the other hand, TPCK eliminated the remaining activity (Figure 4).

\section{Involvement of proteasome in ATP-dependent suppression of DNA fragmentation}

Since proteasome is the ATP-dependent machinery for protein degradation, it might contribute to the suppression of DNA fragmentation by ATP addition. To clarify this, we tested proteasome inhibitors, LLnL and lactacystin, in a cell-free assay. No detectable activity of DNA fragmentation was induced by up to $100 \mu \mathrm{M} L L n L$ or lactacystin (Figure $5 \mathrm{~A}$ ), although induction of apoptosis in HL-60 cells by $50 \mu \mathrm{M} \mathrm{LLnL}$ has been reported previously. ${ }^{33}$ On the contrary, proteasome inhibitors reversed the ATP-dependent suppression of DNA fragmentation in a dose-dependent manner (Figure 5A,B).

These results were further confirmed by agarose gel electrophoresis, which showed the fragmentation detected by ELISA to be internucleosomal in nature. As shown in Figure 5C, ATP addition prevented the DNA cleaving activity of ATP-depleted cytosol (Figure 5C, lane 2), and the effect was abrogated by LLnL (Figure 5C, lane 3) or lactacystin (data not shown). Although caspases are known to be degraded by proteasome, the restored activity was not caspase-dependent (Figure 5C, lanes 4 and 5). In

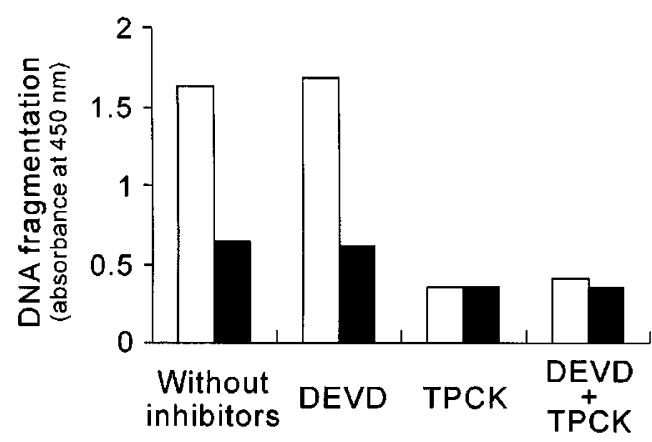

Figure 4 Effect of ATP addition to ATP-depleted cytosol. Cytosol $(2.5 \mathrm{mg} / \mathrm{ml})$ of ATP-depleted HL-60 cells was incubated with 0.2 mM DEVD, $0.2 \mathrm{mM}$ TPCK or both at $37^{\circ} \mathrm{C}$ for $10 \mathrm{~min}$, and then with (filled bars) or without $1 \mathrm{mM} \mathrm{ATP}$ (open bars) at $37^{\circ} \mathrm{C}$ for $1 \mathrm{~h}$. Subsequently, the cytosol was incubated with $1 \times 10^{7} \mathrm{BrdU}-$-labeled nuclei at $37^{\circ} \mathrm{C}$ for $1 \mathrm{~h}$ before ELISA of DNA-fragmenting activity

contrast, TPCK completely inhibited the activity of ATPdepleted cytosol even in the presence of proteasome inhibitors (data not shown). Thus, these results indicate that the serine protease and/or its downstream factors responsible for DNA fragmentation can be degraded by proteasome.

Addition of ATP to normal cytosol in the presence of proteasome inhibitors slightly generated fragmented DNA (Figure 5A,B). This minimal cleavage was unrelated to proteasome inhibitors, since ATP addition alone could induce DNA fragmentation (Figure 5C, lane 10). This activity was abrogated by caspase inhibitors, suggesting slight caspase activation during sample preparation (Figure 5C, lanes 12 and 13).

Finally, the effect of proteasome inhibitors on cells cultured under normal conditions was examined. DNA fragmentation occurred in HL-60 cells incubated with LLnL 

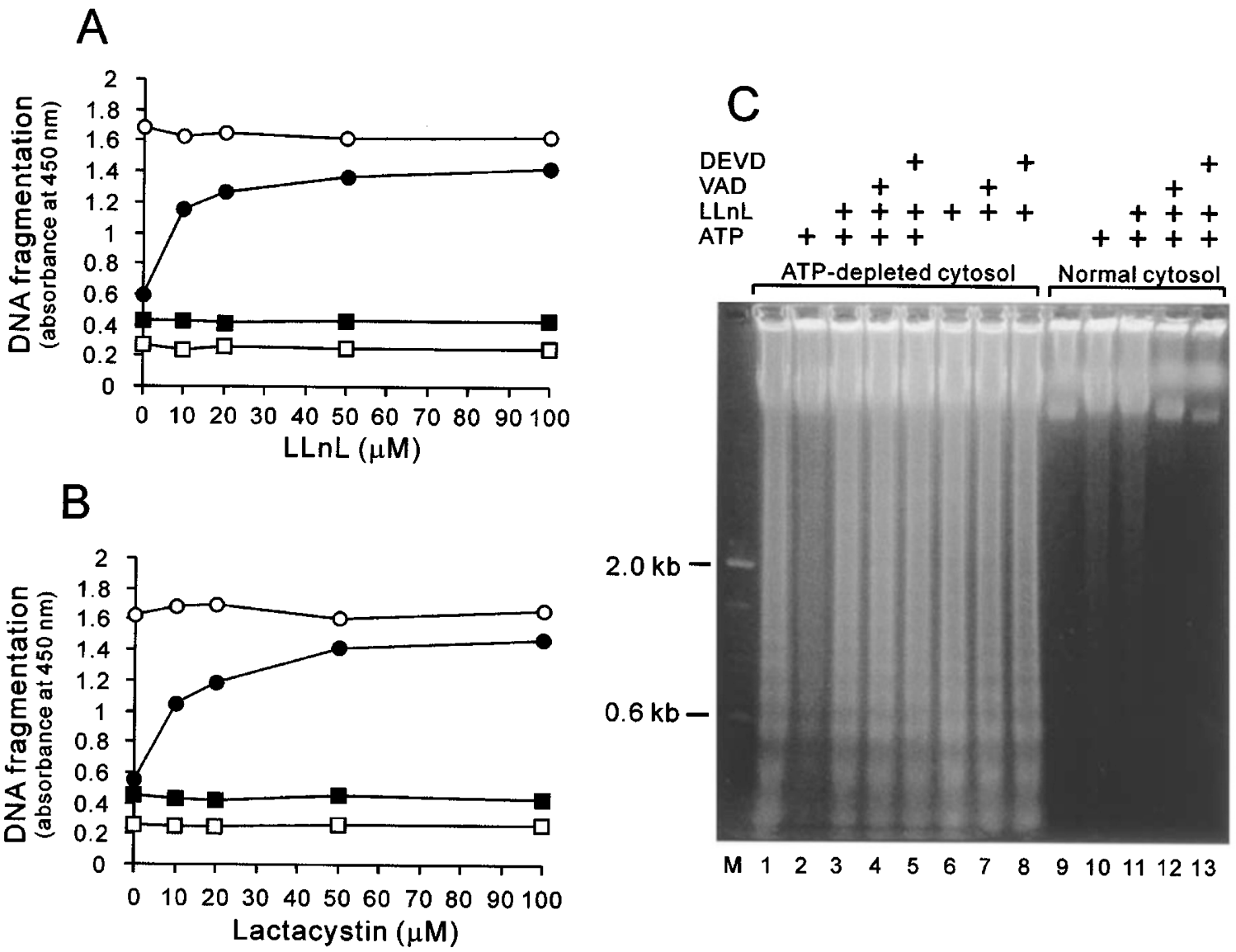

Figure 5 Effect of proteasome inhibitors on ATP-dependent suppression of DNA fragmentation. ATP-depleted cytosol (2.5 mg/ml) was incubated at $37^{\circ} \mathrm{C}$ for 10 min with various concentrations of $L L n L(A)$ or lactacystin $(\mathbf{B})$ in the presence of ATP, and DNA fragmenting activity was measured by ELISA. Closed circles, ATP-depleted cytosol with $1 \mathrm{mM}$ ATP; open circles, ATP-depleted cytosol without ATP; closed squares, normal cytosol with 1 mM ATP; open squares, normal cytosol without ATP. (C) ATP-depleted cytosol (lanes 1-8) or normal cytosol (lanes 9-13) was incubated consecutively with $0.2 \mathrm{mM}$ VAD or DEVD, $0.1 \mathrm{mM}$ LLnL and $1 \mathrm{mM} \mathrm{ATP}$, each at $37^{\circ} \mathrm{C}$ for $10 \mathrm{~min}$. After incubation, the cytosol was incubated with intact nuclei, and DNA was extracted and analyzed by agarose gel electrophoresis

or lactacystin, and was not prevented by TPCK or caspase inhibitors (data not shown).

\section{Discussion}

Internucleosomal DNA cleavage occurred in the early phase of cellular alterations of HL-60 cells when cultured in glucosefree medium. This phenomenon was also observed in other cells including Jurkat T cells (Figure 3 ) and endothelial cells (data not shown). DNA fragmentation was augmented by additional treatment with oligomycin, which inhibits mitochondrial ATP generation and decreases intracellular ATP level to below $10 \%$. In contrast, DNA fragmentation was not observed under glucose-supplied conditions, even in the presence of oligomycin, suggesting that glycolysis is sufficient to prevent this kind of DNA fragmentation.

In the present study, HL-60 cells in glucose-free culture did not display cell shrinkage, membrane blebbing or any other morphological features of apoptosis, probably because these alterations are brought about through ATPdependent mechanisms. ${ }^{16,17,35,36}$ This is consistent with the earlier studies of ATP depletion by Nicotera and
Tsujimoto, ${ }^{37-39}$ but apparent contradiction is the detection of internucleosomal DNA fragmentation, which may be dependent on the sensitivity of gel electrophoresis (see Materials and Methods). The DNA fragmentation induced by ATP depletion is detectable before the 'smear' pattern is evident, and it does not require caspase activation.

In a cell-free system, the activity responsible for internucleosomal endonucleolysis was demonstrated in the cytosol of ATP-depleted cells. DNA fragmentation activity was abolished by inhibition of serine proteases, but not of caspases. These results indicate that serine protease(s) play a key role upstream of endonuclease in DNA cleavage, and that caspases do not participate in the pathway. In addition, CAD/DFF40 is not the final executor endonuclease, because ICAD/DFF45 could not prevent the activity. To date, several studies have suggested involvement of serine protease(s) in the pathway leading to internucleosomal DNA cleavage in different cells and in response to various stimuli. However, the features of these activities seem to be distinct from that observed in the present study, especially relating to caspasedependency. For example, in HL-60 cells treated with a topoisomerase inhibitor, camptothecin or etoposide, proteo- 
lytic activity that is inhibited by a serine protease inhibitor and mediates endonuclease activation ${ }^{29-31}$ has been reported, but this serine protease requires upstream caspase for activation. Wright et al. purified a $24-\mathrm{kDa}$ serine protease that activates DNA fragmentation in UV light-treated U937 histiocytic lymphoma cells. ${ }^{26,40-42}$ This protease was resistant to TLCK and was not activated in ATP-depleted HL-60 cells. Granzyme is a well-known serine protease that can activate apoptotic DNA fragmentation, ${ }^{43-46}$ which is mediated by downstream caspase activation. In MOe7 myeloid progenitor cells, caspase-independent and TPCKsensitive activity is generated in response to cytokine withdrawal, but it was resistant to TLCK. ${ }^{47}$ The only exception is a serine protease activated by camptothecin, but not by etoposide, in a human hepatocellular carcinoma cell line Hep-3B, where the apoptotic pathway operates without caspase activation. ${ }^{32}$ Isolation of the DNA fragmentation activity from the ATP-depleted cytosol is under way to clarify the relationship between these activities.

In the apoptotic pathway driven by caspase to internucleosomal DNA fragmentation, caspase-3 cleaves ICAD/DFF45 and activates CAD/DFF40 endonuclease. ${ }^{25,34-36,48,49}$ In the present study, ICAD/DFF45 blocked the DNA fragmentation induced by etoposide as well as FAS ligation in Jurkat cells (Figure 3). This was an unexpected result because etoposide-induced DNA fragmentation was blocked by TPCK in an earlier study. ${ }^{29,50} \mathrm{An}$ additional pathway involving serine protease(s) may be present upstream of CAD/DFF40 activation.

Proteasome is a multicatalytic protease complex responsible for most non-lysosomal interactions. ${ }^{51-53}$ Recent studies have revealed the involvement of proteasome in the apoptotic process by using proteasome inhibitors. The action is contradictory, though many studies have used proteasome inhibitors to demonstrate the induction of apoptosis. In the present study, the DNAcleaving activity generated in ATP-depleted cytosol was decreased by incubation with ATP, and proteasome inhibitors restored the activity under this ATP-supplied conditions. These results suggest a function of proteasome to eliminate the incidental appearance of DNA-fragmenting activity and favor cells with a survival advantage in adverse environments, e.g. hypoxia and ischemia.

The proteasome inhibitor-mediated restoration of DNA fragmenting activity was suppressed by TPCK in the cell-free system. On the contrary, apoptotic DNA fragmentation was observed in HL-60 cells cultured under normal conditions with proteasome inhibitors, but it was not inhibited by TPCK or by caspase inhibitors. In the latter case where defective degradation of short-lived proteins relevant to cell cycle progression may trigger apoptosis, ${ }^{33,54-56}$ serine proteases do not principally participate in this kind of DNA fragmentation pathway as well as caspases. ${ }^{57}$

\section{Materials and Methods}

\section{Materials}

Caspase inhibitors, carbobenzoxyl-Val-Ala-Asp-fluoromethyl ketone (VAD) and acetyl-Asp-Glu-Val-Asp-aldehyde (DEVD), were from
Bachem AG (Bubendorf, Switzerland) and Peptide Institute, Inc. (Osaka, Japan) respectively. Cycloheximide, N-tosyl-L-lysyl chloromethyl ketone (TLCK), tosyl-L-phenylalanyl chloromethyl ketone (TPCK), 3,4-dichloroisocoumarin (DCI), N-acetyl-leucinyl-leucinylnorleucinal $(\mathrm{LLnL})$ and oligomycin were purchased from Sigma (St. Louis, MO, USA). Lactacystin was from Calbiochem (La Jolla, CA, USA). ATP was from Oriental Yeast (Tokyo, Japan). Monoclonal antihuman Fas (cytocidal IgM clone 7C11) was from Immunotech (Marseille, France). Control IgM was from DAKO (Carpinteria, CA, USA). Etoposide was from Wako (Osaka, Japan). RPMI1640 was from Nikken (Kyoto, Japan). RNase I was purchased from AmershamPharmacia Biotech (Bucks, UK) and was prepared for use by boiling for $10 \mathrm{~min}$ to remove DNase activity.

Oligomycin, protease inhibitors and proteasome inhibitors were dissolved in dimethylsulfoxide (DMSO), and ATP was dissolved in distilled water.

\section{Cells, culture and ATP depletion}

$\mathrm{HL}-60$ promyelocytic leukemia cells and Jurkat $\mathrm{T}$ cells were grown at $37^{\circ} \mathrm{C}$ under $5 \% \mathrm{CO}_{2}$, with humidified air in RPMl 1640 medium supplemented with $10 \%$ fetal bovine serum (FBS) and $2 \mathrm{mM}$ glutamine. The logarithmically growing cells were used for experiments at a density less than $5 \times 10^{5}$ cells $/ \mathrm{ml}$. ATP depletion of the cells was carried out by replacing the medium with glucose-free medium containing oligomycin. Intracellular ATP levels were determined with a kit utilizing the luciferin-luciferase system (Toyo Ink, Tokyo, Japan) according to the manufacturer's instructions.

\section{Gel electrophoresis}

ATP-depleted cells were washed twice with ice-cold phosphatebuffered saline (PBS), incubated in lysis buffer $(10 \mathrm{mM}$ Tris- $\mathrm{HCl}$, $\mathrm{pH}$ 8.0, $20 \mathrm{mM}$ EDTA, $10 \mathrm{mM}$ EGTA, $0.5 \%$ SDS, $0.5 \mathrm{mg} / \mathrm{ml}$ RNase) at $37^{\circ} \mathrm{C}$ for $3 \mathrm{~h}$ and treated with $0.5 \mathrm{mg} / \mathrm{ml}$ proteinase $\mathrm{K}$ at $65^{\circ} \mathrm{C}$ for $3 \mathrm{~h}$. After extraction with phenol, DNA samples were electrophoresed on $1.2 \%$ agarose gels. To secure sufficient sensitivity and resolution, DNA from $1 \times 10^{7}$ cells was loaded on a large gel (15 mm in thickness, $150 \mathrm{~mm}$ in length), and stained with $0.5 \mu \mathrm{g} / \mathrm{ml}$ ethidium bromide at $4^{\circ} \mathrm{C}$ overnight before fluorography.

\section{Cell-free system}

In a typical reaction system, $1 \times 10^{7} \mathrm{HL}-60$ cells were used for preparing isolated nuclei and test cytosol. Cells were washed three times with ice-cold PBS, and suspended in $1 \mathrm{ml}$ ice-cold nucleus buffer $(0.25 \mathrm{M}$ sucrose, $50 \mathrm{mM}$ HEPES, $50 \mathrm{mM} \mathrm{KCl}, 1 \mathrm{mM} \mathrm{MgCl}$, $\mathrm{pH} 7.5$ ) containing $0.1 \% \mathrm{NP}-40$. Following incubation for $10 \mathrm{~min}$ on ice, the cells were lyzed by vortex, and centrifuged at $2000 \mathrm{~g}$ for $5 \mathrm{~min}$ at $4^{\circ} \mathrm{C}$. The supernatant $(2.5 \mathrm{mg}$ protein) was adjusted to $1 \mathrm{ml}$ with nucleus buffer without NP-40 and used as test cytosol for subsequent analysis. The precipitated nuclei were suspended and washed twice with nucleus buffer and stored at $-80^{\circ} \mathrm{C}$ until use. The $1 \times 10^{7}$ nuclei were incubated with the cytosol $(2.5 \mathrm{mg}$ protein) in $1 \mathrm{ml}$ reaction volume at $37^{\circ} \mathrm{C}$ for $1 \mathrm{~h}$ in the presence of test reagents including protease inhibitors, and DNA fragmentation was analyzed by enzymelinked immunosorbent assay (ELISA) as described below. For gel electrophoresis of fragmented DNA, the incubation mixture of nuclei and test cytosol was directly dissolved in lysis buffer, and then DNA was extracted for analysis. 


\section{ELISA of fragmented DNA}

Fragmented DNA was measured using a Cellular DNA Fragmentation ELISA kit (Boehringer Mannheim GmbH, Mannheim, Germany), based on immunological measurement of 5-bromo-2'-deoxyuridine (BrdU)labeled DNA as described previously. ${ }^{58}$ Briefly, HL-60 cells were cultured for $16-20 \mathrm{~h}$ in the presence of $10 \mu \mathrm{M}$ BrdU, and the nuclei were isolated. The $1 \times 10^{7}$ labeled nuclei were incubated with test cytosol (2.5 mg protein) in $1 \mathrm{ml}$ reaction volume, and the mixture was centrifuged at $2000 \mathrm{~g}$ at $4^{\circ} \mathrm{C}$ for $5 \mathrm{~min}$. The supernatant was subjected to ELISA of the cleaved DNA that leaked out from the nucleus. Values were expressed as the mean of triplicate measurements.

\section{Recombinant ICAD/DFF45}

A full length cDNA of ICAD/DFF45 was obtained by reversetranscription polymerase chain reaction carried out on RNA from $\mathrm{HL}$ 60 cells using primers $5^{\prime}$-GGAGGTGACCGGGGAC-3' (forward) and 5'-CTATGTGGGATCCTGTCTGGC-3' (reverse). The amplified cDNA was inserted into pGEX-2T expression vector (Amersham-Pharmacia Biotech), and a glutathione S-transferase fusion protein GST-ICAD/ DFF45 was purified by ion-exchange chromatography using a Mono-Q column (Amersham-Pharmacia Biotech).

To examine the effect of ICAD/DFF45 on the DNA-fragmenting activity of HL-60 cells in a cell-free system, the cytosol ( $2.5 \mathrm{mg}$ protein/ $\mathrm{ml}$ ) from ATP-depleted cells was incubated with $10 \mu \mathrm{M}$ DEVD to inactivate caspase- 3 and then with GST-ICAD/DFF45, each at $4^{\circ} \mathrm{C}$ for $30 \mathrm{~min} .{ }^{25}$ Subsequently, the mixture was incubated with $1 \times 10^{7} \mathrm{BrdU}$ labeled nuclei at $37^{\circ} \mathrm{C}$ for $1 \mathrm{~h}$, followed by ELISA of fragmented DNA.

For Jurkat cells, the effect of ICAD/DFF45 was examined similarly by the method for HL-60 cells described above, except for the cell-free assay in which $5 \times 10^{5}$ BrdU-labeled nuclei and $20 \mu \mathrm{g}$ of test cytosol were incubated in a $20 \mu$ s solution at $30^{\circ} \mathrm{C}$ for $2 \mathrm{~h}$. Test cytosol was prepared from the cells, which were incubated with $0.1 \mu \mathrm{g} / \mathrm{ml}$ anti-FAS $7 \mathrm{C} 11$ antibody or mouse control $\mathrm{IgM}$ at $37^{\circ} \mathrm{C}$ for $18 \mathrm{~h}$, with $0.1 \mathrm{mM}$ etoposide at $37^{\circ} \mathrm{C}$ for $18 \mathrm{~h}$, or with $20 \mu \mathrm{M}$ oligomycin in glucose-free medium at $37^{\circ} \mathrm{C}$ for $6 \mathrm{~h}$ beforehand.

\section{Acknowledgments}

The authors would like to thank M Sakamoto for her technical assistance. This work was supported in part by grants-in-aid from the Ministry of Education, Science, Sports and Culture of Japan, and Uehara Memorial Foundation, and Naito Foundation.

\section{References}

1. Marchetti P, Susin SA, Decaudin D, Gamen S, Castedo M, Hirsch T, Zamzami N, Naval J, Senik A and Kroemer G (1996) Apotosis-associated derangement of mitochondrial function in cells lacking mitochondrial DNA. Cancer Res. 56: 2033-2038

2. vander Heiden MG, Chandel NS, Williamson EK, Schumacker PT and Thompson CB (1997) Bcl- $X_{L}$ regulates the membrane potential and volume homeostasis of mitochondria. Cell 91: 627-637

3. Susin SA, Lorenzo HK, Zamzami N, Marzo I, Brenner C, Larochette N, Prévost MC, Alzari PM and Kroemer G (1999) Mitochondrial release of caspase-2 and -9 during the apoptotic process. J. Exp. Med. 189: 381-394

4. Susin SA, Lorenzo HK, Zamzami N, Marzo I, Snow BE, Brothers GM, Mangion J, Jacotot E, Costantini P, Loeffler M, Larochette N, Goodlett DR, Aebersold R, Siderovski DP, Penninger JM and Kroemer G (1999) Molecular characterization of mitochondrial apoptosis-inducing factor. Nature 397: 441-446
5. Bortner CD and Cidlowski JA (1999) Caspase Independent/dependent regulation of $\mathrm{K}^{+}$, cell shrinkage, and mitochondrial membrane potential during lymphocyte apoptosis. J. Biol. Chem. 274: 21953-21962

6. Scaffidi C, Schmitz I, Zha J, Korsmeyer SJ, Krammer PH and Peter ME (1999) Differential modulation of apoptosis sensitivity in CD95 type I and Type IIcells. J. Biol. Chem. 274: 22532-22538

7. Yin X-M, Wang K, Gross A, Zhao Y, Zinkel S, Klocke B, Roth KA and Korsmeyer SJ (1999) Bid-deficient mice are resistant to Fas-induced hepatocellular apoptosis. Nature 400: 886-891

8. Zou H, Henzel WJ, Liu X, Lutschg A and Wang X (1997) Apaf-1, a human protein homologous to C.elegans CED-4, participates in cytochrome c-dependent activation of caspase-3. Cell 90: 405-413

9. Li P, Nijhawan D, Buduhardjo I, Srinivasula SM, Ahmad M, Alnemri ES and Wang X (1997) Cytochrome $c$ and dATP-dependent formation Apaf-1/Caspase-9 complex initiates an apoptotic protease cascade. Cell 91: 479-489

10. Cecconi F, Alvarez-Bolado G, Meyer BI, Roth KA and Gruss P (1998) Apaf-1 (CED-4 homolog) regulates programmed cell death in mammalian development. Cell 94: 727-737

11. YoshidaH, Kong Y-Y, Yoshida R, Elia AJ, Hakem A, Hakem R, Penninger JM and Mak TW (1998) Apaf1 is required for mitochondrial pathways of apoptosis and brain development. Cell 94: 739-750

12. Hu Y, Benedict MA, Ding L and Núñez G (1999) Role of cytochrome c and dATP/ ATP hydrolysis in Apaf-1-mediated caspase-9 activation and apoptosis. EMBO J. 18: $3586-3595$

13. Mesner Jr PW, Bible KC, Martins LM, Kottke TJ, Srinivasula SM, Svingen PA, Chilcote TJ, Basi GS, Tung JS, Krajewski S, Reed JC, Alnemri ES, Earnshaw WC and Kaufmann SH (1999) Characterization of caspase processing and activation in HL-60 cell cytosol under cell-free conditions. J. Biol. Chem. 274: 2263522645

14. Cain K, Brown DG, Langlais C and Cohen GM (1999) Caspase activation involves the formation of the aposome, a large ( $\sim 700 \mathrm{kDa})$ caspase-activating complex. J. Biol. Chem. 274: 22686-22692

15. Cosulich SC, Savory PJ and Clarke PR (1999) Bcl-2 regulates amplification of caspase activation by cytochrome c. Curr. Biol. 9: 147-150

16. Eguchi Y, Shimizu S and Tsujimoto Y (1997) Intracellular ATP levels determine cell death fate by apoptosis or necrosis. Cancer Res. 57: 1835-1840

17. Yasuhara N, Eguchi $Y$, Tachibana $T$, Imamoto N, Yoneda $Y$ and Tsujimoto $Y$ (1997) Essential role of active nuclear transport in apoptosis. Genes Cells 2:5564

18. Wyllie AH, Kerr JF and Currie AR (1980) Cell death: the significance of apoptosis. Int. Rev. Cytol. 68: 251-306

19. Garland JM and Halestrap A (1997) Energy metabolism during apoptosis. J. Biol. Chem. 272: 4680-4688

20. Kan O, Baldwin SA and Whetton AD (1994) Apoptosis is regulated by the rate of glucose transport in an interleukin 3 dependent cell line. J. Exp. Med. 180: 917 923

21. Carmeliet $P$, Dor $Y$, Herbert J-M, Fukumura D, Brusselmans $K$, Dewerchin $M$, Neeman M, Bono F, Abramovitch R, Maxwell P, Koch CJ, Ratcliffe P, Moons L, Jain RK, Collen D and Keshet E (1998) Role of HIF-1 $\alpha$ in hypoxia-mediated apoptosis, cell proliferation and tumour angiogenesis. Nature 394: 485-490

22. Zamzami N, Marchetti P, Castedo M, Decaudin D, Macho A, Hirsch T, Susin SA, PetitPX, Mignotte B and Kroemer G(1995) Sequential reduction of mitochondrial transmembrane potential and generation of reactive oxygen species in early programmed cell death. J. Exp. Med. 182: 367-377

23. vander Heiden MG, Chandel NS, Schumacker PT and Thompson CB (1999) Bcl$X_{L}$ prevents cell death following growth factor withdrawal by facilitating mitochondrial ATP/ADP exchange. Mol. Cell 3: 159-167

24. Burkart V, WangZ-Q, Radons J, HellerB, Herceg Z, StingI L, WagnerEF and Kolb $H$ (1999) Mice lacking the poly(ADP-ribose) polymerase gene are resistant to pancreatic beta-cell destruction and diabetes development induced by streptozocin. Nat. Med. 5: 314-319

25. Enari M, Sakahira H, Yokoyama H, Okawa K, Iwamatsu A and Nagata S (1998) A caspase-activated DNase that degrades DNA during apoptosis, and its inhibitor ICAD. Nature 391: 43-50

26. Wright SC, Wei QS, Zhong J, Zheng H, Kinder DH and Larrick JW (1994) Purification of a $24-\mathrm{kD}$ protease from apoptotic tumor cells that activates DNA fragmentation. J. Exp. Med. 180: 2113-2123 
27. Chow SC, Weis M, Kass GE, Holmström TH, Eriksson JE and Orrenius S (1995) Involvement of multiple proteases during Fas-mediated apoptosis in $T$ lymphocytes. FEBS Lett. 364: 134-138

28. Schlegel J, Peters I and Orrenius S (1995) Isolation and partial characterization of a protease involved in Fas-induced apoptosis. FEBS Lett. 364: 139-142

29. Yoshida A, Takauji R, Inuzuka M, Ueda T and Nakamura T (1996) Role of serine and ICE-like protease in induction of apoptosis by etoposide in human leukemia HL-60 cells. Leukemia 10: 821-824

30. Shimizu T and Pommier Y (1996) DNA fragmentation induced by protease activation in p53-null human leukemia HL60 cells undergoing apoptosis following treatment with the topoisomerase I inhibitor camptothecin: cell-free system studies. Exp. Cell Res. 226, 292-301

31. Shimizu T and Pommier Y (1997) Camptothecin-induced apoptosis in p53-null human leukemia HL60 cells and their isolated nuclei: effects of the protease inhibitors Z-VAD-fmk and dichloroisocoumarin suggest an involvement of both caspases and serine proteases. Leukemia 11: 1238-1244

32. Adjei PN, Kaufmann SH, Leung WY, Mao F and Gores GJ (1996) Selective induction of apoptosis in Hep $3 \mathrm{~B}$ cells by topoisomerase linhibitors: Evidence for a protease-dependent pathway that does not activate cysteine protease P32. J. Clin. Invest. 98: 2588-2596

33. Drexler HCA (1997) Activation of the cell death program by inhibition of proteasome function. Proc. Natl. Acad. Sci. USA 94: 855-860

34. Sakahira H, Enari M and Nagata S (1998) Cleavage of CAD inhibitor in CAD activation and DNA degradation during apoptosis. Nature 391: $96-99$

35. Sahara S, Aoto M, Eguchi Y, Imamoto N, Yoneda Y and Tsujimoto Y (1999) Acinus is a caspase-3-activated protein required for apoptotic chromatin condensation. Nature 401: 168-173

36. Samejima K, Toné S, Kottke TJ, Enari M, Sakahira H, Cooke CA, Durrieu F, Martins LM, Nagata S, Kaufmann SH and Earnshaw WC (1998) Transition from caspase-dependent to caspase-independent mechanisms at the onset of apoptotic execution. J. Cell Biol. 143: 225-239

37. Leist M, Single B, Castoldi AF, Kühnle $S$ and Nicotera $P$ (1997) Intracellular adenosine triphosphate (ATP) concentration: a switch in the decision between apoptosis and necrosis. J. Exp. Med. 185: 1481-1486

38. Leist M, Single B, Naumann H, Fava E, Simon B, Kühnle S and Nicotera P (1999) Inhibition of mitochondrial ATP generation by nitric oxide switches apoptosis to necrosis. Exp. Cell Res. 249: 396-403

39. Eguchi Y, Srinivasan A, Tomaselli KJ, Shimizu S and Tsujimoto Y (1999) ATPdependent steps in apoptotic signal transduction. Cancer Res. 59: 2174-2181

40. Wright SC, Wei QS, Kinder DH and Larrick JW (1996) Biochemical pathways of apoptosis: Nicotinamide adenine dinucleotide-deficient cells are resistant to tumor necrosis factor or ultraviolet light activation of the $24-\mathrm{kD}$ apoptotic protease and DNA fragmentation. J. Exp. Med. 183: 463-471

41. Wright SC, Schellenberger U, Ji L, Wang H and Larrick JW (1997) Calmodulindependent protein kinase II mediates signal transduction in apoptosis. FASEBJ. 11: $843-849$

42. Wright SC, Schellenberger $\mathrm{U}$, Wang $\mathrm{H}$, Kinder DH, Talhouk JW and Larrick JW (1997) Activation of CPP32-like proteases is not sufficient to trigger apoptosis: inhibition of apoptosis by agents that suppress activation of AP24, but not CPP32-like activity. J. Exp. Med. 186: 1107-1117
43. Heusel JW, Wesselschmidt RL, Shresta S, Russell JH and Ley TJ (1994) Cytotoxic lymphocytes require granzyme $B$ for the rapid induction of DNA fragmentation and apoptosis in allogeneic target cells. Cell 76: 977-987

44. Darmon AJ, Nicholson DW and Bleackley RC (1995) Activation of the apoptotic protease CPP32 by cytotoxic T-cell-derived granzyme B. Nature 377: 446-448

45. Trapani JA, Browne KA, Smyth MJ and Jans DA (1996) Localization of granzyme $B$ in the nucleus. J. Biol. Chem. 271: 4127-4133

46. Martin SJ, Amarante-Mendes GP, Shi L, Chuang T-H, Casiano CA, O'Brien GA, Fitzgerald P, Tan EM, Bokoch GM, Greenberg AH and Green DR (1996) The cytotoxic cell protease granzyme $B$ initiates apoptosis in a cell free system by proteolytic processing and activation of the ICE/CED-3 family protease, CPP32, via a novel two-step mechanism. EMBO J. 15: 2407-2416

47. Wu L-W, Reid S, Ritchie A, Broxmeyer HE and Donner DB (1999) The proteasome regulates caspase-dependent and caspase-independent protease cascades during apoptosis of MO7e hematopoetic progenitor cells. Blood Cells Mol. Dis. 25: 20-29

48. Zhang J, Liu X, Scherer DC, van Kaer Lv, Wang X and Xu M (1998) Resistance to DNA fragmentation and chromatin condensation in mice lacking the DNA fragmentation factor 45. Proc. Natl. Acad. Sci. USA 95: 12480-12485

49. Liu X, Zou H, Slaughter C and Wang X (1997) DFF, a heterodimeric protein that functions downstream of caspase-3 to trigger DNA fragmentation during apoptosis. Cell 89: 175-184

50. Yoshida A, Pourquier P and Pommier Y (1998) Purification and characterization of a $\mathrm{Mg}^{2+}$-dependent endonuclease (AN34) from etoposide-treated human leukemia HL-60 cells undergoing apoptosis. Cancer Res. 58: 2576-2582

51. Ciechanover $A$ (1998) The ubiquitin-proteasome pathway: on protein death and cell life. EMBO J. 17: 7151-7160

52. Baumeister W, Walz J, Zühl F and Seemüller E (1998) The proteasome: paradigm of a self-compartmentalizing protease. Cell 92: $367-380$

53. Orlowski RZ (1999) The role of the ubiquitin-proteasome pathway in apoptosis. Cell Death Differ. 6: 303-313

54. Lin K-I, Baraban JM and Ratan RR (1998) Inhibition versus induction of apoptosis by proteasome inhibitors depends on concentration. Cell Death Differ. 5: 577583

55. Tomoda K, Kubota Y and Kato J (1999) Degradation of the cyclin-dependentkinase inhibitor p27 $7^{\text {Kip } 1}$ is instigated by Jab 1. Nature 398: 160-165

56. Chang YC, Lee YS, Tejima T, Tanaka K, Omura S, Heintz NH, Mitsui Y and Magae J (1998) Mdm2 and bax, downstream mediators of the p53 response, are degraded by the ubiquitin-proteasome pathway. Cell Growth Differ. 9: 79-84

57. Monney L, Otter I, Olivier R, Ozer HL, Haas AL, Omura S and Borner C (1998) Defects in the ubiquitin pathway induce caspase-independent apoptosis blocked by Bcl-2. J. Biol. Chem. 273: 6121-6131

58. Nakamura N, Ban T, Yamaji K, Yoneda Y and Wada Y (1998) Localization of the apoptosis-inducing activity of lupus anticoagulant in an annexin V-binding antibody subset. J. Clin. Invest. 101: 1951-1959 